\title{
Translational cancer biology
}

\author{
Cristina Maccalli
}

We are excited to announce the launch of a new section in the Journal of Translational Medicine entitled "Translational Cancer Biology". This section aims to provide a platform for the communication and dissemination of advances in cancer biology and their translational applications. Studies considered for publication include those dissecting the mechanisms of transformation, progression and metastatization, the biology of cancer stem cells and their immunological properties, the mechanisms undergoing the epithelial-to mesenchymal (EMT) transition and tumor dormancy, their relationship with immune functions and the mechanisms undergoing cancer resistance to therapies. This section is also dedicated to those investigations dedicated to the translational aspects and the development of novel therapies related to the aforementioned themes and the identification of patient's responsiveness and outcome to therapies.

Cancer is one of the leading causes of morbidity and mortality in the western world. The progress in understanding the oncogenic and pro-survival pathways as well as the immunological profile of cancer cells allowed to design novel targeted therapies and immunotherapy, leading to the improvement of the overall survival of cancer patients. Nevertheless, a significant proportion of cancer patients are unresponsive or develop resistance to therapies. Advances in genome sequencing allowed to show that tumor lesions results from heterogeneous mixture of genetically distinct subclones that arise through tumor evolution [1-3]. The unique driver mutations within each subclone can impact the cancer hallmarks differently, thereby contributing to functional heterogeneity. In addition, a variety of DNA mutations arise at different stage and dynamically along with tumor

*Correspondence: cmaccalli@sidra.org

Sidra Medicine, Doha, Qatar development and progression $[4,5]$. These genetic variants together with epigenetic modifications drive the development of hierarchically organized neoplastic tissues comprising subpopulations of self-renewing cells with "stemness" properties that allow the long term maintenance of tumors. The evidence that rare cells within tumor lesions, cancer stem cells/cancer initiating cells (CSCs/CICs), represent a key component of tumor initiation and propagation was obtained initially in hematological malignancies [6,7] and subsequently in solid tumors with different histological origins [8-11].

$\mathrm{CSCs} / \mathrm{CICs}$ are endowed with the ability to modulate their proliferative status from quiescent to slow or fast cycling $[12,13]$ and with the resistance to therapeutic treatment, such as chemotherapy and radiotherapy [14-20]. These cells can survive and initiate the formation of local recurrence, and through migrating at distant site, of metastases, even many years after the initial clinical response to the treatments [19, 21-24]. One of the major factor influencing the phenotype, molecular properties and proliferative status of CSCs/CICs is represented by the "niche" or tumor microenvironment (TME) $[25,26]$. The epithelial-to-mesenchymal transition (EMT) is a developmental program underlying the acquisition of mesenchymal properties by epithelial cells $[27,28]$. EMT become re-activated in cancer cells, promoting cell migration, dissemination of cells and metastasis formation $[29,30]$ and is associated with the generation of CSCs/CICs [31, 32]. The identification of key signaling pathways underlying CSCs/CICs properties would more accurately provide insights for the clinical contribution and significance of these cells [33-36]. Epigenetic mechanisms, including DNA methylation, histone modifications, chromatin remodeling and changes in non-coding RNA, such as miRNAs, regulate the landscape of cells. The deregulation of these genomic make-up can increase stemness and self-renew, 
contributing to the development of CSCs/CICs [37-39]. A complex connection of molecular signaling can be deregulated by aberrant epigenetic modification during the course of tumor formation contributing to the maintenance and proliferation of CSCs/CICs, as well as resistance to therapies and tumor progression. Progress in dissecting the molecular pathways underlying CSC/ $\mathrm{CIC}$ properties lead to the identification of some of the mechanisms that can render this subpopulation of cells resistant to therapy, such as high levels of anti-apoptotic signaling [40], DNA repair molecules [41], up-regulation of cellular extrusion pumps [42], increased aldehyde dehydrogenase (ALDH), metabolic activity [43], up-regulation of IL-4 signaling-dependent resistance to apoptosis [44]. Nevertheless, others key mechanisms underlying this phenomenon still need to be dissected and fully understood.

The mechanisms underlying dormant state of tumor cells are not fully understood. Cellular quiescence, the genomic make up of tumor cells, angiogenesis and the crosstalk with TME and immune responses can influence and shape tumor cell properties. Among these mechanisms, CSCs/CICs can be relevant component of tumor dormancy [45]. The presence of dormant cells, through their escape from immune recognition, may lead to tumor recurrence and metastatization. The understanding of the molecular pathway of cancer biology and stemness represent a major endeavor for the discovery and validation of biomarker signatures associated with the therapeutic efficacy and for the identification of more effective precision medicine interventions.

The Journal of Translational Medicine through providing high standard peer-review process represents a platform for efficient communication of up-to-date results and scientific discussions. The Translational Cancer Biology section will guarantee high quality and competitive publications. The Editorial Board is looking forward to receiving your contributions.

Published online: 23 September 2020

\section{References}

1. Gerlinger M, Rowan AJ, Horswell S, Larkin J, Endesfelder D, Gronroos E, Martinez P, Matthews N, Stewart A, Tarpey P, et al. Intratumor heterogeneity and branched evolution revealed by multiregion sequencing. $N$ Engl J Med. 2012;366(10):883-92.

2. Garraway LA, Lander ES. Lessons from the cancer genome. Cell. 2013;153(1):17-37.

3. Greaves M, Maley CC. Clonal evolution in cancer. Nature. 2012;481(7381):306-13.

4. Clevers $\mathrm{H}$. The cancer stem cell: premises, promises and challenges. Nat Med. 2011;17(3):313-9.
5. Kreso A, Dick JE. Evolution of the cancer stem cell model. Cell Stem Cell. 2014;14(3):275-91.

6. Bonnet D, Dick JE. Human acute myeloid leukemia is organized as a hierarchy that originates from a primitive hematopoietic cell. Nat Med. 1997;3(7):730-7.

7. Ladoire S, Mignot G, Dabakuyo S, Arnould L, Apetoh L, Rebe C, Coudert B, Martin F, Bizollon MH, Vanoli A, et al. In situ immune response after neoadjuvant chemotherapy for breast cancer predicts survival. J Pathol. 2011;224(3):389-400.

8. Ricci-Vitiani L, Lombardi DG, Pilozzi E, Biffoni M, Todaro M, Peschle C, De Maria R. Identification and expansion of human colon-cancer-initiating cells. Nature. 2007;445(7123):111-5.

9. Singh SK, Hawkins C, Clarke ID, Squire JA, Bayani J, Hide T, Henkelman RM, Cusimano MD, Dirks PB. Identification of human brain tumour initiating cells. Nature. 2004;432(7015):396-401.

10. Schatton T, Murphy GF, Frank NY, Yamaura K, Waaga-Gasser AM, Gasser M, Zhan Q, Jordan S, Duncan LM, Weishaupt C, et al. Identification of cells initiating human melanomas. Nature. 2008;451(7176):345-9.

11. Al-Hajj M, Wicha MS, Benito-Hernandez A, Morrison SJ, Clarke MF. Prospective identification of tumorigenic breast cancer cells. Proc Natl Acad Sci USA. 2003;100(7):3983-8.

12. Wilson $A$, Laurenti $E$, Oser $G$, van der Wath $R C$, Blanco-Bose W, Jaworski M, Offner S, Dunant CF, Eshkind L, Bockamp E, et al. Hematopoietic stem cells reversibly switch from dormancy to self-renewal during homeostasis and repair. Cell. 2008;135(6):1118-29.

13. Fuchs $E$. The tortoise and the hair: slow-cycling cells in the stem cell race. Cell. 2009;137(5):811-9.

14. Al-Ejeh F, Smart CE, Morrison BJ, Chenevix-Trench G, Lopez JA, Lakhani SR, Brown MP, Khanna KK. Breast cancer stem cells: treatment resistance and therapeutic opportunities. Carcinogenesis. 2011;32(5):650-8.

15. Catalano V. Resistance of cancer stem cells to cell-mediated immune responses, vol. 15. Berlin: Springer; 2015.

16. Codony-Servat J, Rosell R. Cancer stem cells and immunoresistance: clinical implications and solutions. Transl Lung Cancer Res. 2015;4(6):689-703.

17. Diehn M, Clarke MF. Cancer stem cells and radiotherapy: new insights into tumor radioresistance. J Natl Cancer Inst. 2006;98(24):1755-7.

18. Eyler CE, Rich JN. Survival of the fittest: cancer stem cells in therapeutic resistance and angiogenesis. J Clin Oncol. 2008;26(17):2839-45.

19. Maugeri-Sacca M, Vigneri P, De Maria R. Cancer stem cells and chemosensitivity. Clin Cancer Res. 2011;17(15):4942-7.

20. Steinbichler TB, Dudas J, Skvortsov S, Ganswindt U, Riechelmann H, Skvortsova, II. Therapy resistance mediated by cancer stem cells. In: Semin Cancer Biol. 2018.

21. Maccalli C, De Maria R. Cancer stem cells: perspectives for therapeutic targeting. Cancer Immunol Immunother. 2015;64(1):91-7.

22. Chery L, Lam HM, Coleman I, Lakely B, Coleman R, Larson S, AguirreGhiso JA, Xia J, Gulati R, Nelson PS, et al. Characterization of single disseminated prostate cancer cells reveals tumor cell heterogeneity and identifies dormancy associated pathways. Oncotarget. 2014:5(20):9939-51.

23. Hosseini H, Obradovic MM, Hoffmann M, Harper KL, Sosa MS, WernerKlein M, Nanduri LK, Werno C, Ehrl C, Maneck M, et al. Early dissemination seeds metastasis in breast cancer. Nature. 2016;540(7634):552-8.

24. Maccalli C, Parmiani G, Ferrone S. Immunomodulating and immunoresistance properties of cancer-initiating cells: implications for the clinical success of immunotherapy. Immunol Investig. 2017;46(3):221-38.

25. Siegel PM, Massague J. Cytostatic and apoptotic actions of TGF-beta in homeostasis and cancer. Nat Rev Cancer. 2003;3(11):807-21.

26. Soltanian S, Matin MM. Cancer stem cells and cancer therapy. Tumour Biol. 2011;32(3):425-40.

27. Thiery JP, Acloque H, Huang RY, Nieto MA. Epithelial-mesenchymal transitions in development and disease. Cell. 2009;139(5):871-90.

28. Tomaskovic-Crook E, Thompson EW, Thiery JP. Epithelial to mesenchymal transition and breast cancer. Breast Cancer Res. 2009;11(6):213.

29. Mani SA, Guo W, Liao MJ, Eaton EN, Ayyanan A, Zhou AY, Brooks M, Reinhard F, Zhang CC, Shipitsin M, et al. The epithelial-mesenchymal transition generates cells with properties of stem cells. Cell. 2008;133(4):704-15.

30. Scheel C, Weinberg RA. Cancer stem cells and epithelial-mesenchymal transition: concepts and molecular links. Semin Cancer Biol. 2012;22(5-6):396-403. 
31. Morel AP, Lievre M, Thomas C, Hinkal G, Ansieau S, Puisieux A. Generation of breast cancer stem cells through epithelial-mesenchymal transition. PLOS ONE. 2008;3(8):e2888.

32. Pradella D, Naro C, Sette C, Ghigna C. EMT and stemness: flexible processes tuned by alternative splicing in development and cancer progression. Mol Cancer. 2017;16(1):8.

33. Lim SJ, Tan TW, Tong JC. Computational epigenetics: the new scientific paradigm. Bioinformation. 2010;4(7):331-7.

34. Eppert K, Takenaka K, Lechman ER, Waldron L, Nilsson B, van Galen P, Metzeler KH, Poeppl A, Ling V, Beyene J, et al. Stem cell gene expression programs influence clinical outcome in human leukemia. Nat Med. 2011;17(9):1086-93.

35. Lamb J, Crawford ED, Peck D, Modell JW, Blat IC, Wrobel MJ, Lerner J, Brunet JP, Subramanian A, Ross KN, et al. The Connectivity Map: using gene-expression signatures to connect small molecules, genes, and disease. Science. 2006;313(5795):1929-35.

36. Shats I, Gatza ML, Chang JT, Mori S, Wang J, Rich J, Nevins JR. Using a stem cell-based signature to guide therapeutic selection in cancer. Cancer Res. 2011;71(5):1772-800.

37. Cui $P$, Zhang L, Lin Q, Ding F, Xin C, Fang X, Hu S, Yu J. A novel mechanism of epigenetic regulation: nucleosome-space occupancy. Biochem Biophys Res Commun. 2010;391(1):884-9.

38. Wang LH, Choi YL, Hua XY, Shin YK, Song YJ, Youn SJ, Yun HY, Park SM, Kim WJ, Kim HJ, et al. Increased expression of sonic hedgehog and altered methylation of its promoter region in gastric cancer and its related lesions. Mod Pathol. 2006;19(5):675-83.

39. Duan ZH, Wang HC, Zhao DM, Ji XX, Song M, Yang XJ, Cui W. Cooperatively transcriptional and epigenetic regulation of sonic hedgehog overexpression drives malignant potential of breast cancer. Cancer Sci. 2015;106(8):1084-91.

40. Liu D, Martin V, Fueyo J, Lee OH, Xu J, Cortes-Santiago N, Alonso MM, Aldape K, Colman H, Gomez-Manzano C. Tie2/TEK modulates the interaction of glioma and brain tumor stem cells with endothelial cells and promotes an invasive phenotype. Oncotarget. 2010;1 (8):700-9.

41. Bao S, Wu Q, McLendon RE, Hao Y, Shi Q, Hjelmeland AB, Dewhirst MW, Bigner DD, Rich JN. Glioma stem cells promote radioresistance by preferential activation of the DNA damage response. Nature. 2006;444(7120):756-60.

42. Wu ZB, Qiu C, Zhang AL, Cai L, Lin SJ, Yao Y, Tang QS, Xu M, Hua W, Chu YW, et al. Glioma-associated antigen HEATR1 induces functional cytotoxic T Iymphocytes in patients with glioma. J Immunol Res. 2014;2014:131494

43. Ginestier C, Hur MH, Charafe-Jauffret E, Monville F, Dutcher J, Brown M, Jacquemier J, Viens P, Kleer CG, Liu S, et al. ALDH1 is a marker of normal and malignant human mammary stem cells and a predictor of poor clinical outcome. Cell Stem Cell. 2007;1(5):555-67.

44. Francipane MG, Alea MP, Lombardo Y, Todaro M, Medema JP, Stassi G. Crucial role of interleukin-4 in the survival of colon cancer stem cells. Cancer Res. 2008;68(11):4022-5.

45. Maccalli C, Rasul Kl, Elawad M, Ferrone S: The role of cancer stem cells in the modulation of anti-tumor immune responses. In: Semin Cancer Biol. 2018 .

\section{Publisher's Note}

Springer Nature remains neutral with regard to jurisdictional claims in published maps and institutional affiliations.
Ready to submit your research? Choose BMC and benefit from:

- fast, convenient online submission

- thorough peer review by experienced researchers in your field

- rapid publication on acceptance

- support for research data, including large and complex data types

- gold Open Access which fosters wider collaboration and increased citations

- maximum visibility for your research: over 100M website views per year

At BMC, research is always in progress.

Learn more biomedcentral.com/submissions 